International Research Journal of Management, IT \& Social Sciences
Available online at https://sloap.org/journals/index.php/irjmis/
Vol. 6 No. 5, September 2019, pages: 118 125
ISSN: 2395-7492
https://doi.org/10.21744/irjmis.v6n5.708

\title{
Dividend Policy, Leverage, and Institutional Ownership as Agency Problem Control Mechanisms in Privatized Indonesian State-Owned Enterprises
}

Made Ratih Nurmalasari ${ }^{a}$

I Gde Kajeng Baskara ${ }^{\text {b }}$

Article history:

Received: 18 March 2019

Accepted: 31 May 2019

Published: 23 August 2019

\section{Keywords:}

agency problem;

dividend policy;

firm value;

institutional ownership;

leverage;

\begin{abstract}
This study aims to test the agency theory in privatized Indonesian State-Owned Enterprises. The agency problem in this study was proxied by firm value (Tobin's Q) while the agency problem control mechanism was proxied by institutional ownership, leverage, and dividend policy. This study examines the interchangeable relations between the three variables. The data used in this study are secondary data sourced from the Indonesia Stock Exchange. The research sample is all SOEcompanies that meet the criteria and are listed on the Indonesia Stock Exchange in the 2013-2017 observation period. The analytical tool used in this study was 2SLS (Two-Stage Least Square) with panel data techniques and simultaneous models. The results showed that dividend policy and institutional ownership have a substitution relationship in reducing agency problems, whereas leverage and dividend policy, as well as institutional ownership and leverage, do not have a substitute relationship in reducing agency problems.
\end{abstract}

2395-7492@ Copyright 2019. The Author. This is an open-access article under the CC BY-SA license (https://creativecommons.org/licenses/by-sa/4.0/) All rights reserved.

\section{Author correspondence:}

Made Ratih Nurmalasari,

Faculty of Economic and Business Udayana University, Denpasar, Indonesia.

Email address: maderatihnurmalasari@gmail.com

\section{Introduction}

Nowadays, several SOEs have been privatized, one of the aims is to control agency problems through a share ownership structure. According to Law Number 19 of 2003 concerning State-Owned Enterprises, privatization is the sale of shares of a state-owned enterprise which is a limited liability company with shares of at least $51 \%$ owned by the Republic of Indonesia, either partially or wholly to other parties in order to improve performance and the firm value, enlarging the benefits for the country and society, and expanding community ownership of shares.

a Udayana University, Denpasar, Indonesia

${ }^{\mathrm{b}}$ Udayana University, Denpasar, Indonesia 
The conversion of part of government ownership into public ownership has led to oversight of SOE performance not only by the government but also by the public, especially investors (Ayu, 2018). More optimal oversight is expected to be able to control the actions of managers to suit the interests of shareholders (Uwugibe, 2013). According to Aprilina (2013), privatization carried out by SOEs will change the SOEs culture, so that SOEs truly concentrate on achieving their main mission of maximizing shareholder wealth. The increase in shareholders' wealth shows an increase in the welfare of shareholders which has an impact on increasing the firm value.

In Indonesia, the ownership of SOEs shares that go public is mostly owned by institutions such as banks, consumer finance companies, leasing companies, insurance companies, investment companies, mutual fund companies, and pension fund companies. Institutional shareholders become monitoring agents, which means that supervisory activities previously carried out by the principal and incurring monitoring costs can be reduced, so this study uses institutional ownership as an indicator of ownership structure.

The amount of cash available in the company makes managers often use the cash to finance projects that benefit managers so that dividend policy can be a control mechanism for the emergence of agency problems because it reduces the cash flow that is in manager's control (Rozeff, 1982 \& Easterbrook, 1984). Dividend policy can be seen from the calculation of dividend payout ratio which is the amount of dividend paid by the company compared to the company's profit. Dividend payments cause the company's free cash flow under the control of managers to reduce opportunities for managers to make extravagance through expenditures that are not beneficial to improving the welfare of shareholders and will affect the decrease in agency costs, namely residual loss (Iryanto \& Wahyudi, 2010). High dividend payments can also be a positive signal for investors to increase firm value (Osamwonyi \& Lola-Ebueku, 2016).

Just like dividend payments, increased use of debt will encourage managers to act in a disciplined manner providing future cash flow for debt and interest payments which causes the company's free cash flow under manager's control to decrease (Jensen, 1986). The level of debt used in a company is calculated using a leverage ratio by measuring the number of assets that are credited by creditors so that creditors will increase supervision of managers and supervisory activities previously carried out by the principal and lead to reduced monitoring costs.

Based on this, the dividend policy, leverage, and institutional ownership have the same function, namely as a mechanism to control agency problems in privatized SOEs. Therefore, the three mechanisms should have a mutually replacing relationship. This means that one mechanism can replace the other mechanism in controlling agency problems which are reflected in the firm value. The mutually changing relationship is reflected in the significant negative relationship between the three mechanisms.

There are still different research results regarding the relationship between the three control mechanisms. Research by Asad \& Yousaf (2014), found that the high use of debt will reduce the level of dividend payments because profit distribution is prioritized to pay off debt rather than being paid as dividends. A similar case was also stated by Uwuigbe (2013), that companies with high financial leverage tend to pay lower dividends. Research conducted by Rahma \& Anisb (2017), found that there was no significant relationship between leverage and dividend policy. According to the results of research conducted by Javeed et al., (2017), there is a significant relationship between leverage and firm value which is moderated by the structure of scattered ownership, meaning that the structure of scattered ownership reinforces the increase in firm value. The greater portion of institutional investor ownership will also reduce the level of dividend distribution (Al-Qahtani \& Ajina, 2017; Yanti \& Dwirandra, 2019; Putri \& Sujana, 2018). The results of the study by Olufawoye et al., (2017), precisely states that the supervision by the shareholders is spread does not significantly affect the distribution of dividends (Olufawoye et al., 2017). Similar to the results of Vo \& Nguyen (2014), which found that ownership structure, dividend policy, and partial leverage had no significant effect. Sari (2016), found that there is a mutually changing relationship between leverage and dividend policy and leverage with ownership structures as a mechanism for controlling agency problems. Meanwhile, research by Hardjopranoto (2006), concluded that the interlocking relationship between the three dividend policies, leverage, and ownership structure in the role of oversight of agency problems did not fully occur. This then raises the research gap research.

\section{Literature Review and Hypothesis}

According to Brigham \& Daves (2016), an increase in debt is interpreted by outsiders about the company's ability to pay obligations in the future or low business risk, this will be responded positively by the market. Research by Harris \& Raviv (1990), which states that leverage positively affects firm value. The share of scattered share ownership will encourage increased oversight that is more optimal for the company's management performance (Uwuigbe, 2013). Increased supervision by institutions results in an optimal performance of the company being monitored and avoided

Nurmalasari, M. R., \& Baskara, I. G. K. (2019). Dividend policy, leverage, and institutional ownership as agency problem control mechanisms in privatized Indonesian state-owned enterprises. International Research Journal of Management, IT and Social Sciences, 6(5), 118-125. https://doi.org/10.21744/irjmis.v6n5.708 
opportunistic behavior so that managers will act in accordance with the wishes of shareholders. Large institutional ownership will carry out active supervision so that managers direct all policies and efforts to maximize firm value (Sari, 2016).

From a company perspective, institutional ownership can reduce agency conflicts. When the company is owned by an institution, the company will be controlled externally so that the company prioritizes long-term interests, for example, if the company decides to pay dividends then this happens if the company has already made an investment and improved the company's performance so that the remaining funds are used to pay dividends. This is supported by the results of research by Al-Qahtani \& Ajina (2017) that there is a negative relationship between institutional investor ownership and the level of dividend distribution. Research by Putri \& Nasir (2006) \& Aghara et al., (2018), suggests the results that high dividend payments will reduce agency costs so that the existence of institutions as a monitoring mechanism is no longer needed.

The mutually changing relationship is reflected by a significant negative relationship between the two variables. This means that one machine can replace the other mechanism in controlling agency problems which are reflected in the firm value. Rahma \& Anisb (2017), found a substitution relationship between dividend and debt policies. Likewise with Vo \& Nguyen (2014), which states that dividend payments have a negative impact on leverage. A negative effect was also found by Sisca (2008). He stated that the higher the debt policy, the lower the dividend policy. If the company has a high level of debt, then the company is trying to reduce the agency cost of debt by reducing its debt. Debt reduction can be done by financing investments with internal funding sources so that shareholders will give up their dividends to finance their investments.

The mutually changing relationship is reflected by a significant negative relationship between the two variables. This means that one machine can replace the other mechanism in controlling agency problems which are reflected in the firm value. The results of the study by Hardjopranoto (2006), state that there is a negative relationship between institutional ownership and leverage policy. Likewise with research by Vo \& Nguyen (2014), that institutional ownership negatively affects leverage. The results of this study are consistent with Rahma \& Anisb (2017), research which shows that companies with institutional and personal ownership will payout low dividends and use debt at low levels. While Mukonyi et al., (2014), stated that there was a statistically significant negative relationship between institutional, personal, and foreign ownership of corporate leverage.

\section{Hypothesis}

H1: There is a significant simultaneous effect between dividend policy, leverage, and institutional ownership on the value of privatized Indonesian SOEs

$\mathrm{H} 2$ : There is a mutually changing relationship between dividend policy and institutional ownership as an agency problem control mechanism for privatized Indonesian SOEs

H3: There is a mutually changing relationship between dividend policy and leverage as an agency problem control mechanism for privatized Indonesian SOEs

H4: There is a mutually changing relationship between leverage and institutional ownership as a mechanism for controlling agency problems in privatized Indonesian SOEs

\section{Materials and Methods}

This type of research is causality research that aims to explain the relationship between two or more variables quantitatively through hypothesis testing. While the research approach used is quantitative research, namely the research procedures that produce research data in the form of statistical figures that will be used as material for analysis. The scope of the research includes the object of research, namely firm value, and three agency problem control mechanisms, namely dividend policy, leverage, and institutional ownership which are limited to state-owned enterprises that have privatized and listed on the Indonesia Stock Exchange for five years, from 2013 to 2017. 


\section{Results and Discussions}

\subsection{Result}

Table 1

Regression Result of institutional ownership, dividend policy, and leverage on firm value

\begin{tabular}{llcc}
\hline $\begin{array}{l}\text { Dependent Variable: } \\
\text { Firm Value }\end{array}$ & Coefficient & Standard Error & Probability \\
\hline Constanta & 2,008916 & 0,087820 & 0,0000 \\
Institutional Ownership & 2,995046 & 0,239470 & 0,0000 \\
Leverage & $-2,409548$ & 0,046140 & 0,0000 \\
Dividend Policy & $-0,309133$ & 0,029759 & 0,0000 \\
F-statistic (Prob.) & & $1.028,667(0,000000)$ \\
R-square & & \multicolumn{2}{c}{0,976560} \\
\hline
\end{tabular}

Primary Data, 2019

Based on Table 1, the results show that the F-statistic value of 0.000000 is smaller than the 0.05 significance level, meaning that institutional ownership, dividend policy, and leverage simultaneously have a significant effect on the value of the company which is proxied by Tobin's $Q$ ratio at 5\% alpha with business risk, company size, fixed asset structure, and share growth as control variables. Institutional ownership has a significant positive relationship to firm value with a regression coefficient of 2.995046 which means that each increase in 1 unit of institutional ownership will increase the value of the company by 2.995046 units assuming other variables are constant. Leverage has a significant negative relationship to the value of the company with a regression coefficient of -2.409548 which means that each increase in the leverage level of 1 unit will reduce the value of the company by 2.409548 units assuming other variables are constant. Dividend policy has a significant negative relationship to firm value with a regression coefficient of 0.309133 which means that every 1 unit increase in the dividend policy rate will decrease the value of the company by 0.309133 units assuming other variables are constant.

Table 2

Regression result of dividend policy and institutional ownership

\begin{tabular}{llll}
\hline $\begin{array}{l}\text { Dependent Variable: } \\
\text { Institutional Ownership }\end{array}$ & Coefficient & Standard Error & Probability \\
\hline Constanta & 0,364393 & 0,021539 & 0,0000 \\
\hline Leverage & $-0,034156$ & 0,026542 & 0,2023 \\
\hline Dividend Policy & $-0,060847$ & 0,020208 & 0,0036 \\
\hline F-statistic (Prob.) & & $8,498402(0,000486)$ &
\end{tabular}

Primary Data, 2019

Based on Table 2, the results show that the F-statistic value of 0,000486 is smaller than the significance level of 0.05 , meaning that dividend policy and leverage simultaneously have a significant effect on institutional ownership. Dividend policy partially has a significant negative effect on institutional ownership at alpha 5\% with business risk, company size, fixed asset structure, and growth stock as control variables. The regression coefficient of -0.060847 means that each increase in the dividend policy rate of 1 unit will reduce the level of institutional ownership by 0.060847 units.

Table 3

Regression Result of Dividend Policy and Leverage

\begin{tabular}{llll}
\hline Dependent Variable: & Coefficient & Standard Error & Probability \\
Dividend Policy & $-0,036999$ & 0,347751 & 0,9156 \\
\hline Constanta & 0,002184 & 0,182719 & 0,9905 \\
Leverage & 0,806466 & 0,943557 & 0,3955 \\
Institutional Ownership & . & \\
\hline
\end{tabular}

Nurmalasari, M. R., \& Baskara, I. G. K. (2019). Dividend policy, leverage, and institutional ownership as agency problem control mechanisms in privatized Indonesian state-owned enterprises. International Research Journal of Management, IT and Social Sciences, 6(5), 118-125. https://doi.org/10.21744/irjmis.v6n5.708 


\begin{tabular}{cc}
\hline F-statistic (Prob.) & $0,366898(0,694168)$ \\
\hline Primary Data, 2019 &
\end{tabular}

Based on Table 3, the results show that the F-statistic value of 0.694168 is greater than the 0.05 significance level, meaning that leverage has no significant effect on dividend policy with business risk, company size, fixed asset structure, and stock growth as control variables.

Tabel 4

Regression Result of Leverage and Institutional Ownership

\begin{tabular}{llll}
\hline $\begin{array}{l}\text { Dependent Variable: } \\
\text { Leverage }\end{array}$ & Coefficient & Standard Error & Probability \\
\hline Constanta & 0,895314 & 0,361031 & 0,0155 \\
Institutional Ownership & $-0,355119$ & 1,134083 & 0,7551 \\
Dividend Policy & $-0,001132$ & 0,082220 & 0,9891 \\
F-statistic (Prob.) & & $0,058546(0,943179)$ & \\
\hline
\end{tabular}

Primary Data, 2019

Based on Table 4, the results show that the F-statistic value of 0.943179 is greater than the 0.05 significance level, meaning that institutional ownership has no significant effect on leverage with business risk, company size, fixed asset structure, and stock growth as control variables.

\subsection{Discussion}

Based on Table 1, the results show that institutional ownership, dividend policy, and leverage simultaneously have a significant effect on the firm value which is proxied by Tobin's Q ratio at $5 \%$ alpha. It can be seen that institutional ownership has a significant positive relationship to the firm value which indicates that the higher the level of institutional ownership of the company, the value of the company will increase. An increase in institutional ownership results in managers avoiding opportunistic behavior because the manager's performance is monitored optimally to achieve shareholder goals, namely increasing the value of the company, so as to reduce agency problems.

It can also be seen that leverage has a significant negative relationship to company value, which indicates that the lower the use of corporate debt, the value of the company will increase, and vice versa. After the optimal point, the use of debt will actually reduce the value of the company because the increase in profits from the use of debt is not proportional to the increase in the cost of financial distress and agency problems.

The results also showed that the dividend policy had a significant negative relationship to the value of the company which showed that the lower the dividends distributed by the company, the higher the company's value, and vice versa. This can be caused by low dividends indicating that the ratio of retained earnings is high, this shows that the company's investment prospects in the future are good.

Based on Table 2, the results show that the dividend policy has a significant negative effect on institutional ownership at alpha 5\%, which shows that the dividend policy is a substitute for institutional ownership as a mechanism of controlling agency problems in a state-owned enterprise in Indonesia that privatize. The results of this study are consistent with research conducted by Jensen et al., (1999), who found a negative relationship with institutional ownership and dividend policy. From a company perspective, institutional ownership can reduce agency conflicts. When the company's shares are more institutionally owned, the company will be controlled externally so if the company decides to pay dividends, this will happen if the company has invested and improved the company's performance so that the remaining funds are used to pay dividends. This is supported by research results by Putri $\&$ Nasir (2006), which suggests that high dividend payments will reduce agency costs so that the existence of institutions as a monitoring mechanism is no longer needed.

Based on Table 3, the results show that leverage does not have a significant effect on dividend policy, meaning that the high or low leverage of the company does not affect the dividend policy adopted by the company, which shows that the average Indonesian state-owned enterprise prefers internal funding policy first, namely retained earnings, then after that it uses debt and issues shares to meet its funding. This condition might cause that leverage does not have an impact on dividend policy during this research period. The results of this study differ from the results of research by Rahma \& Anisb (2017); Vo \& Nguyen (2014); Hommel (2011); and Sisca (2008), which state that the higher the debt 
policy, the lower the dividend policy. But the results of this study are supported by research conducted by Fira (2009), which shows that leverage has no effect on dividend policy.

Based on Table 4, the results show that institutional ownership does not have a significant effect on leverage, meaning that the level of company institutional ownership does not affect the level of corporate debt use. Unlike the results of research by Hardjopranoto (2006); Vo \& Nguyen (2014); Rahma \& Anisb (2017); and Mukonyi et al., (2014), which states that there is a statistically significant negative relationship between institutional ownership and corporate leverage. This study was supported by Sugama (2018) who obtained the result that institutional ownership had no effect on leverage. This can be caused by the highest proportion of shares ownership still owned by the government in accordance with regulations related to the privatization of Indonesian SOEs, which is a minimum of $51 \%$ of total shares. The government is more inclined to emphasize the objectives or policies in the political and social fields, in other words, the benefits from the use of debt are not the main objectives of the current government.

\section{Conclusion}

Simultaneous analysis of institutional ownership, leverage, and dividend policy related to mechanisms that can reduce agency problems. The separation between ownership and control of the company creates a conflict of interest between shareholders and managers who can pursue other objectives that are different from shareholders maximizing wealth. These results provide evidence of the mechanism for controlling the company through institutional ownership, dividend payments and also the use of leverage decided by the company. For shareholders, this research is expected to be a consideration for investors to see the condition of the company in terms of ownership structure, leverage, and dividends that are distributed and provide information about the actual condition of the company and used as a means of monitoring the company. For managers, this research is expected to be used as a material consideration in decision making which can then be used to improve the competitive advantage of a company.

\section{Research Limitations}

This research is inseparable from limitations due to constraints and conditions in several respects. The limitation of the research experienced by the author is that it only focuses on state-owned enterprise listed on the Indonesia Stock Exchange that have distributed successive dividends for five years, namely from 2013 to 2017 so that there are only 15 SOEs that match the criteria for determining the sample. It is expected that the limitations experienced by researchers can be considered for further research.

\section{Conflict of interest statement}

The authors declared that they have no competing interest.

\section{Statement of authorship}

The authors have a responsibility for the conception and design of the study. The authors have approved the final article.

\section{Acknowledgments}

The authors would like to thank the editor of IRJMIS for their valuable time, support, and advice in completing the present research.

Nurmalasari, M. R., \& Baskara, I. G. K. (2019). Dividend policy, leverage, and institutional ownership as agency problem control mechanisms in privatized Indonesian state-owned enterprises. International Research Journal of Management, IT and Social Sciences, 6(5), 118-125. https://doi.org/10.21744/irjmis.v6n5.708 


\section{References}

Aghara, V. N. O., Nwaizugbo, I. C., Oparah, P. C., \& Ifeanyichukwu, C. D. (2018). Sales promotion as a leverage strategy for improving sales and profitability in alcohol beverage industry. International Research Journal of Management, IT and Social Sciences, 5(4), 18-25. https://doi.org/10.21744/irjmis.v5n4.245

Al-Qahtani, T. H., \& AJINA, A. (2017). The Impact of Ownership Structure on Dividend Policy the Evidence from Saudi Arabia. Journal of Emerging Issues in Economics, Finance and Banking, 6(1), 2187-2202.

Aprilina, V. (2013). Dampak Privatisasi pada Kinerja Keuangan Badan Usaha Milik Negara (Bumn) di Indonesia. JRAK: Jurnal Riset Akuntansi dan Komputerisasi Akuntansi, 4(1), 1-12.

Asad, M., \& Yousaf, S. (2014). Impact of leverage on dividend payment behavior of Pakistani Manufacturing Firms. International Journal of Innovation and Applied Studies, 6(2), 216.

AYU, K. P. (2018). Pengaruh privatisasi terhadap kinerja dan nilai perusahaan bumn yang terdaftar di bursa efek indonesia tahun 2015-2017.

Brigham, E. F., \& Daves, P. R. (2016). Intermediate Financial Management, Mason, OH: South--Western Cengage Learning. za:] K. Garskaite-Milvydiene, D. Burksaitiene, Pecularities of Bankruptcies, Restructuring, Mergers and Acquisitions in Lithuania in the Post-Crisis Period, Inzinerine Ekonomika-Engineering Economics, 27(5), 546556.

Dewi, S. C. (2008). Pengaruh kepemilikan managerial, kepemilikan institusional, kebijakan hutang, profitabilitas dan ukuran perusahaan terhadap kebijakan dividen. Jurnal Bisnis dan Akuntansi, 10(1), 47-58. https://doi.org/10.34208/jba.v10i1.252

Easterbrook, F. H. (1984). Two agency-cost explanations of dividends. The American economic review, 74(4), 650659.

Hardjopranoto, W. (2006). Interdependent Analysis of Leverage, Dividend, and Managerial Ownership Policies: Agencies Perspectives. Gadjah Mada International Journal of Business, 8(2), 179-199. https://doi.org/10.22146/gamaijb.5619

Harris, M., \& Raviv, A. (1990). Capital structure and the informational role of debt. The Journal of Finance, 45(2), 321-349. https://doi.org/10.1111/j.1540-6261.1990.tb03693.x

Hommei, M. (2011). Dividend policy and ownership structure in the Netherlands (Doctoral dissertation, Master Thesis Financial Management. Tilburg University).

Iryanto, M. B. W., \& Wahyudi, S. (2010). Mekanisme Bonding Dan Nilai Perusahaan. Jurnal Keuangan dan Perbankan, 14(3).

Javeed, A., Yaqub, R. M. S., \& Aslam, M. A. (2017). Revisiting capital structure and firm value: moderating role of corporate governance: Evidence from Pakistan. European Journal of Business and Management, 9(16), 39-48.

Jensen, M. C. (1986). The Takeover Controversy: Analysis and Evidence." Midland Corporate Finance Journal. Vol. 4 (1986), pp. 6-32. Takeovers, Their Causes and Consequences." Journal of Economic Perspectives, 2, 21.

Jensen, S. S., Berkowicz, R., Hansen, H. S., \& Hertel, O. (2001). A Danish decision-support GIS tool for management of urban air quality and human exposures. Transportation Research Part D: Transport and Environment, 6(4), 229-241. https://doi.org/10.1016/S1361-9209(00)00026-2

Mukonyi, P. M. (2014). The relationship between ownership structure and leverage of firms listed in the Nairobi securities exchange (Doctoral dissertation, Egerton University).

Olufawoye, O. H., Iyoha, A. I., \& Izedonmi, F.. 2017. Agency Cost and Dividend Policy; Evidence From Nigeria. International Journal of Economics, Commerce, and Management. 5(7): 306-333.

Osamwonyi, I. O., \& Lola-Ebueku, I. (2016). Does dividend policy affect firm earnings? Empirical evidence from Nigeria. International Journal of Financial Research, 7(5), 77. http://dx.doi.org/10.5430/ijfr.v7n5p77

Puspita, F. (2009). Analisis Faktor-faktor yang Mempengaruhi Kebijakan Dividend Payout Ratio (Studi Kasus pada Perusahaan yang Terdaftar di Bursa Efek Indonesia Periode 2005-2007)(Doctoral dissertation, Program Pasca Sarjana Universitas Diponegoro).

Putri, I. F., \& Nasir, M. (2006). Analisis Persamaan Simultan Kepemilikan Manajerial, Kepemilikan Institusional, Risiko, Kebijakan Hutang dan Kebijakan Dividen dalam Perspektif Teori Keagenan. Simposium Nasional Akuntansi, 9, 23-26.

Putri, Y. K. W., \& Sujana, I. K. (2018). The influence of bid-ask spread and leverage on earnings management with good corporate governance as moderating variable. International Research Journal of Management, IT and Social Sciences, 5(3), 8-21. 
Rahma, B. \& Anisb, J. (2017). Managerial ownership, Debt and Dividend Policy of Tunisian Companies: Evidence of a Simultaneous Analysis. International Journal of Economics \& Strategic Management of Business Process (ESMB). 10: 21-30.

Rozeff, M. S. (1982). Growth, beta and agency costs as determinants of dividend payout ratios. Journal of financial Research, 5(3), 249-259. https://doi.org/10.1111/j.1475-6803.1982.tb00299.x

Sari, M. M., Said, \& Malasari, Silvia.(2016). Traing Of Caragiver Towards Family Independence Level in Caring For Elderly With Hypertension, 1-7.

Sugama, A. A. (2018). Pengaruh struktur kepemilikan terhadap agency problem pada perusahaan go public yang terdaftar di bursa efek indonesia.

Uwuigbe, U. (2013). An Examination of the effects of Ownership Structure and Financial Leverage on the Dividend Policies of listed firms in Nigeria. Journal of Economics, Business, and Accountancy Ventura, 16(2), 251-258.

Vo, D. H., \& Nguyen, V. T. Y. (2014). Managerial ownership, leverage and dividend policies: Empirical evidence from Vietnam's listed firms. International journal of economics and finance, 6(5), 274-284. http://dx.doi.org/10.5539/ijef.v6n5p274

Yanti, N. M. Y. W. A., \& Dwirandra, A. (2019). The effect of profitability in income smoothing practice with good corporate governance and dividend of payout ratio as a moderation variable. International Research Journal of Management, IT and Social Sciences, 6(2), 12-21. https://doi.org/10.21744/irjmis.v6n2.601

Nurmalasari, M. R., \& Baskara, I. G. K. (2019). Dividend policy, leverage, and institutional ownership as agency problem control mechanisms in privatized Indonesian state-owned enterprises. International Research Journal of Management, IT and Social Sciences, 6(5), 118-125. https://doi.org/10.21744/irjmis.v6n5.708 